\title{
СРАВНИТЕЛЬНАЯ ТОКСИКОЛОГИЧЕСКАЯ ХАРАКТЕРИСТИКА НАНОЧАСТИЦ КОБАЛЬТА, МЕДИ, ОКСИДА МЕДИ И ЦИНКА
}

\begin{abstract}
COMPARATIVE TOXICOLOGICAL CHARACTERISTICS OF COBALT, COPPER, COPPER OXIDE AND ZINC NANOPARTICLES

\section{G. Churilov \\ I. Obidina \\ D. Churilov \\ V. Churilova \\ S. Polishchuk}

Summary. The biological activity of nanoparticles depends on the size, concentration, and chemical composition. Nanoparticles of copper and zinc oxides with a size of $20-80 \mathrm{~nm}$ are accumulated in the structure of plants and inhibit the processes of growth and development. Nanoparticles of iron, copper and cobalt metals with a size of 20-100 $\mathrm{nm}$ have biocompatibility and play the role of growth stimulants. All the studied nanoparticles are not toxic and can be used for contact with living systems: plants and animals, but differently affect their growth dynamics, morphological and biochemical parameters, and oxidative modification of rat thymus proteins. The effect of ultrafine copper powders at a dose of $10-3 \mathrm{mg} / \mathrm{kg}$ and $10-1 \mathrm{mg} / \mathrm{kg}$ on the oxidative modification of rat thymus proteins was studied. It was detected that the oxidative modification of proteins increases dose-dependently with the predominance of protein molecule fragmentation processes for nanoparticles of copper and zinc oxides. Nanoparticles of copper and cobalt metals in doses of $10-3 \mathrm{mg} /$ $\mathrm{kg}$ and $10-1 \mathrm{mg} / \mathrm{kg}$ show a reversible nature of oxidative stress. This conclusion is consistent with morphological and biochemical parameters of rat blood under the influence of copper and cobalt nanoparticles, with sizes of $35-60 \mathrm{~nm}$, cobalt $20 \mathrm{~nm}$, and copper and zinc oxides.
\end{abstract}

Keywords: nanometals, biochemical and morphological indicators, rats, toxicity, accumulation, plants, oxidative modification.
Чурилов Геннадий Иванович

Д.б.н., дочент, ФГБОУ ВО «Рязанский государственный медицинский университет имени академика И.П. Павлова» genchurilov@yandex.ru

Обидина Инна Вячеславовна

Д.б.н., ассистент, ФГБОУ ВО «Рязанский государственный медицинский университет имени академика И.П. Павлова»

inna.obidina@mail.ru

Чурилов Дмитрий Геннадьевич

Д.т.н., дочент, ФГБОУВО «Рязанский государственный агротехнологический университет имени П. А. Костычева» churilov.dmitry@yandex.ru

чурилова Вероника Вячеславовна Аспирант, ФГБОУ ВО «Рязанский государственный агротехнологический университет имени

П. А. Костычева»;

Полищук Светлана Дмитриевна

Профрессор, ФГБОУ ВО «Рязанский государственный агротехнологический университет имени

П. А. Костычева»

svpolishuk@mail.ru

Аннотация. Биологическая активность наночастиц зависит от размеров, концентрации, химического состава. Наночастицы оксидов меди и цинка размером 20-80 нм накапливаются в структуре растений и тормозят процессы роста и развития. Наночастицы металлов железа, меди и кобальта размером 20-100 нм обладают биосовместимостью и выполняют роль стимуляторов роста. Все изучаемые наночастицы не обладают токсичностью и могут быть использованы для контакта с живыми системами: растениями и животными, но по-разному влияют на динамику их роста, морфологические и биохимические показатели и окислительную модификацию белков тимуса крыс. Изучено влияние ультрадисперсных порошков меди в дозе 10-3 мг/кг и 10-1 мг/ кг на окислительную модификацию белков тимуса крыс. Установлено, что дозозависимо повышается окислительная модификация протеинов с преобладанием процессов фрагментации белковых молекул для наночастиц оксидов меди и цинка. Наночастицы металлов меди и кобальта в дозах 10-3 мг/кг и 10-1 мг/кг показывают обратимый характер окислительного стресса. Этот вывод согласуется с морфологическими и биохимическими показателями крови крыс под действием наночастиц меди и кобальта, размерами 35-60 нм, кобальта 20 нм и оксидов меди и цинка.

Ключевые слова: нанометаллы, биохимические и морфологические показатели, крысы, токсичность, аккумуляция, растения, окислительная модификация. 

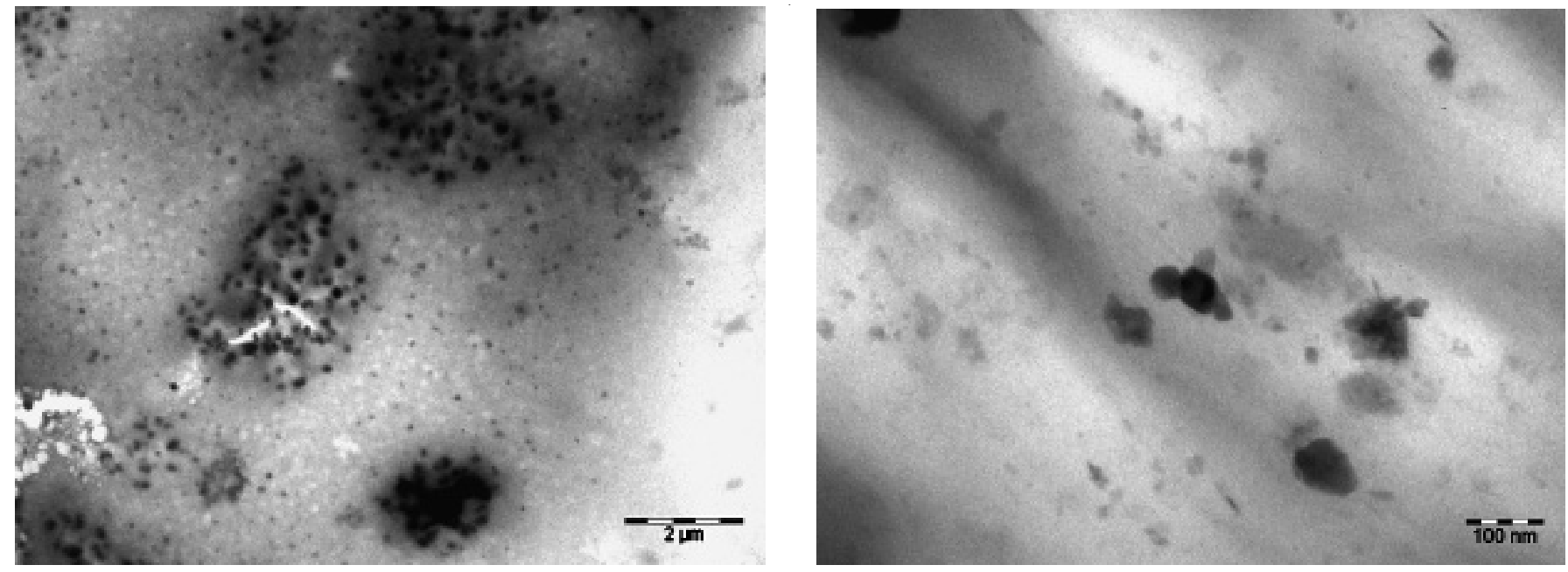

Рис. 1. Проростки вики с видимыми включениями диоксида титана и оксида цинка.

\section{Введение}

H аночастицы металлов железа, меди и кобальта улучшают морфофизиологические и биохимические показатели растений, что дает возможность применения нанометаллов в качестве стимуляторов роста, обладающих пролонгированным действием [1,2,3,4]. Химическое взаимодействие наночастиц с жидкой средой является одним из определяющих факторов их биологической активности. Для наночастиц металлов размером до 65 нм аккумуляция не доказана, но проходимость их в клетку имеет место [5]. При этом изменяется трансмембранный потенциал - повышается энергия, возрастает активность синтеза ферментов и фитогормонов, в частности индолилуксусной кислоты, и рост и развитие растений усиливаются $[6,7,8]$. Биологическая активность наночастиц (НЧ) металлов и оксидов зависит от физико-химических характеристик частиц [9]. Биологические эффекты вызывают различные по физико-химическим свойствам НЧ одного размера, следовательно, причинами этих явлений являются процессы, связанные с действием определенного регуляторного сигнала в биологических системах. Однако направленность этих изменений зависит от химического состава биологически активных НЧ (металлы, оксиды) и от их концентрации, что, видимо, обусловлено изменением структуры мембран в присутствии наночастиц, а это приводит к изменению функционального состояния клетки и смене механизма действия вещества в различном концентрационном интервале.

Высокой биологической активностью обладают наночастицы металлов - железа, кобальта, меди размером 35-60 нм в количестве 0,01-10,0 г на тонну семян, полученные низкотемпературной металлизацией нанодисперсных порошков гидроксидов $[10,24]$. Наночасти- цы оксидов цинка, титана и, в меньшей степени, оксида меди размером 20-80 нм снижают показатели роста и развития растений. В отличие от наночастиц металлов они аккумулируются в структурах растений, понижая активность фитогормонов и ферментов. При этом аномальная дозовая зависимость эффекта в области сверхнизких концентраций биологически активных веществ зарегистрирована на уровне ответа не только клетки или целостного организма (растения), но и отдельных биомакромолекул (ферментов) [11,12,23]. Наночастицы оксидов аккумулируются в структуре растений, что доказано методами сканирующей (СЭМ) и просвечивающей электронной микроскопии (ПЭМ) [13], причиной чему являются:

- их высокая адгезия к поверхностям живых систем;

- отрицательный заряд;

- устойчивое образование агломератов, которые эффективнее задерживаются в клетках растений;

- размер наночастиц.

Стенки растительных клеток полупроницаемы, диаметр пор в стенках составляет 5-20 нм и это позволяют мигрировать маленьким молекулам. Но пропускная способность может меняться, т.к. могут образовываться новые каналы под действием наночастиц, проходящих через мембраны клеток.

Для наночастиц металлов размером до 100 нм аккумуляция не доказана, но проходимость их в клетку имеет место. Такие частицы влияют на рост растений в меньшей степени. Возможно, что из-за своих больших размеров они проникают в семена лишь в незначительном количестве и частично взаимодействуют с клеточными органеллами. Однако при увеличении их концентрации рост надземной части горчицы увеличивается до $12 \%$ по сравнению с контролем, в то время как рост подземной ча- 
сти увеличивается на 30\%. Не исключено, что в процессе биоаккумуляции в клетках происходят некоторые изменения, например, НЧ, действуя на клеточные рецепторы, способствуют возникновению дополнительных каналов для проникновения питательных веществ, что приводит к активации роста и развития растений.

Длина проростков горчицы, семена которых были обработаны наночастицами меди и кобальта размером 200 нм, превышала такие же показатели контрольной группы только при очень высоких концентрациях (1001000 мг/кг). Таким образом, наночастицы любого размера, длительное время контактируя с живыми системами, как было показано на примере наночастиц размером 200 нм, могут перемещаться между организмами разного трофического уровня, подвергаясь разложению и накоплению в пищевой цепи. Следовательно, вопрос о влиянии НЧ на живые системы остается актуальным, и эколого-биологический контроль их воздействия крайне необходим.

Необходимость токсикологической характеристики наночастиц обусловлена наличием острой или подострой токсичности при их непосредственном введении в организм животных. Кроме того, хроническая токсичность также является существенным признаком для определения общей опасности.

\section{Физико-химические} характеристики наночастиц

Физико-химические характеристики определялись такими показателями, как удельная поверхность (м²/г), фазовый состав (\%), распределения размеров наночастиц, форм-фактор. С помощью методов СЭМ, ПЭМ установлены размеры наночастиц. Удельная поверхность изучаемых нанопорошков, полученных химическим способом, измерялась методом низкотемпературной адсорбции азота по БЭТ [14], с использованием анализатopa «Quantachrome NOVA 1200е»: Co 52,1 м²/г (23-46нм); Cu 6,5 м²/г (16-63нм). Форм-фактор для всех <10. Удельная поверхность CuO 90,5 м²/г (10-40 нм); ZnO 37,9 м²/г (18-60 нм). Суспензии наночастиц готовили на основе дистиллированной воды. Навески взвешивали на аналитических весах (Japan, точность $\pm 0,0001$ г), всыпали в емкость с водой объёмом 1 л и перемешивали. Затем диспергировали при помощи ультразвука в течение 5 минут, мощности - 300 Вт, частоте - 23,740 кГц согласно разработанной методике пробоподготовки.

\section{Метолика определения острой и хрОНИЧескОЙ ТОКсИчнОсти}

При определении острой и хронической токсичности НЧ железа, кобальта и меди был определен класс опас- ности и показатели кумулятивности. Опыт проводили в соответствии с «Методическими указаниями по определению токсических свойств препаратов, применяемых в ветеринарии и животноводстве» утвержденных М3 СССР, ВАСХНИЛ, ГУВ Госагропрома СССР (1986). В опыте использовали беспородных белых мышей (массой 19-22 г) и крыс-самцов (массой 200,0-220,0 г). Животных содержали в поликарбонатных клетках по 5 или 10 голов, согласно санитарным правилам в соответствии с Приказом М3 СССР № 1045-73 от 06.04.1973; Правилам лабораторной практики и Приказом МЗ СССР № 1179 от 10.10.1983. Кормление проводили в соответствии с Приказом М3 СССР № 163 от 10.03.1966 о рационе лабораторных животных, следуя методическим указаниям «Стандартизации экологической среды лабораторных животных по фактору питания» (1980). Использовался комбикорм полнорационный экструдированный (для крыс, мышей), ГОСТ Р 51849-2011 Р.5, производство ООО «Лабораторкорм», г. Москва.

Было проведено 3 серии опытов, сформировано 24 группы по 10 мышей. Суспензию НПМ вводили однократно в желудок с помощью зонда в количестве 1 мл, содержащем определенные дозировки. В течение 15 суток проводили наблюдение за общим состоянием и поведением животных, проявлением симптомов интоксикации, приемом корма и воды. Также проведены лабораторные исследования по изучению острой токсичности при внутрижелудочном введении белым крысам. Было проведено 3 серии опытов, сформировано 24 группы по 10 крыс-самцов.

Исследование по изучению хронической токсичности при внутрижелудочном введении белым крысам включало в себя 3 серии опытов на 120 крысах-самцах массой тела 200,0-220,0 г. Выбранные дозы представляли дозировки, кратные значению LD $_{50}$, установленной в остром опыте для перорального введения дозы, которые составляли - 6710,5 мг/кг (железо), 7000,0 мг/кг (медь) и 1233,3 мг/кг (кобальт). Суспензию вводили ежедневно в течение 5 сут. в желудок с помощью зонда в дозах: 1/10; $1 / 20$ и 1/50 от LD 50 . Далее каждые 5 дней увеличивали дозировку в 1,5 раза. Животные находились под ежедневным наблюдением. Контролировали: состояние волосяного покрова и слизистых оболочек, потребление корма и воды, общее поведение. Погибшие животные подвергались вскрытию для определения причин повреждающего действия вещества. Результаты статистически обработаны.

\section{Опрелеление морфологических и биохимических показателей крови}

Для исследования морфологических и биохимических показателей крови опытных животных были сфор- 
мированы группы по 20 особей (крысы-самки), порода - Wistar, живой вес которых находился в пределах 200-220 г. Рацион соответствовал физиологическим нормам и потребностям животных. Контрольная группа получала обычный рацион, особи опытных групп суспензии наночастиц размерами: Со до 20 нм, Со и Сu 35-65 нм, ZnO и CuO 20-80 нм. Наночастицы вводили в расчете 0,02 мг/кг живого веса. Каждые 10 дней проводилось взвешивание и забор крови. На протяжении опыта (30 дней) велись наблюдения за общим физиологическим состоянием, активностью и внешним видом крыс. Изучена их способность НЧ влиять на динамику накопления массы крыс. Морфологические и биохимические показатели крови определяли по стандартным методикам в ветеринарной лаборатории «ВЕTТЕСТ», являющейся участником Федеральной системы внешней оценки качества лабораторных исследований МЗ РФ ФСВОК.

\section{Метолика определения воздействия наночастиц на окислитеАьную моАификацию белков}

Оптическую плотность кетон-динитрофенилгидразонов (КДНФГ) и (АДНФГ) альдегид-динитрофенилгидразонов определяли на спектрофотометре СФ-2000. Исследование проводили на 54 крысах-самках линии Wistar массой 260-320 г. Ткань тимуса очищали в холодном 0,25 М растворе сахарозы в соотношении $1 / 100$, затем гомогенизировали и центрифугировали двадцать минут с целью отделения не полностью разрушенных клеток и ядер. Супернатант для удаления митохондрий центрифугировали 15 мин при $14000 \mathrm{~g}$ для, затем еще 30 мин при 20000 g, чтобы получить собой чистую цитоплазматическую фракцию. Окислительную модификацию белков производили по методу R. L. Levine в модификации Е. Е. Дубининой $[15,16,17]$. Оптическую плотность АДНФГ определяли при 356 и 430 нм, КДНФГ 370 и 530 нм. Степень окислительной модификации белков выражали в единицах оптической плотности, отнесенных на 1 г ткани. Количество битирозина (окислительная модификация тирозиновых остатков белков) и окисленного триптофана оценивали по флуорисцирующей способности продуктов окисления $[18,19]$. Окисление триптофановых остатков сопровождается снижением флуоресценции, характерной для триптофана. Анализ результатов проводили согласно U-критерию Манна-Уитни.

\section{Обсужление результатов}

В результате изучения токсикологических свойств добавок НЧ меди, кобальта, оксидов меди и цинка были получены следующие результаты:

- параметры острого токсического действия при однократном пероральном введении белым крысам:
LD $_{50}$ (HЧ ZnO) - 292,9 мг/кг, LD 50 (HЧ Co) - 1233,3 мг/ Kг, LD LD $_{50}$ (Hч CuO) - 259,2 мг/кг, соответственно, добавки относятся к умеренно опасным веществам - 3 классу опасности;

LD $_{50}$ (HЧ Cu) - 7000,0 мг/кг, соответственно, добавка относится к малоопасным веществам - 4 классу опасности по ГОСТ 12.1.007-76.

- параметры острого токсического действия при однократном пероральном введении белым мышам:

LD $_{50}$ (HЧ Co) - 1033,3 мг/кг, соответственно, добавка относится к умеренно опасным веществам - 3 классу опасности;

$\mathrm{LD}_{50}$ (HЧ Cu) - 5868,4 мг/кг, соответственно, добавка относится к малоопасным веществам - 4 классу опасности по ГОСТ 12.1.007-76.

Кроме того, были определены параметры токсического действия при многократном применении добавок наночастиц белым крысам (хроническая токсичность). В результате проведения опытов в течение 60 суток на белых крысах по определению хронической токсичности добавок в дозах 1/10, 1/20 и 1/50 от средне смертельных доз, установленных в остром опыте, были установлены хронические средне смертельные дозы: $\mathrm{LD}_{50}$ (HЧ ZnO) хрон. $=1183,8 \mathrm{мг} / \mathrm{kг} ;$ LD $_{50}$ (HЧ Со) хрон.4180,8 мг/кг; LD ${ }_{50}$ (HЧ Cu) хрон.- 40650,9 мг/кг; LD 50 (HЧ CuO) хрон. - 580 мг/кг.

Полученные результаты согласуются с ранее установленными классами опасности в опытах по изучению острой пероральной токсичности. Следовательно, изучаемые наночастицы, размером 35-60 нм не обладают токсичностью и могут быть использованы для контакта с живыми системами: растениями и животными.

Интерес представляло сравнение действия наночастиц металлов и наночастиц оксидов металлов на крысах, так как они различаются своими физико-химическими характеристиками и воздействием на растения: оксиды аккумулируются в корнях и проростках, для наночастиц металлов размером до 100 нм аккумуляция не доказана, но проходимость их в клетку имеет место и речь идет о биосовместимости. Для таких наночастиц характерно: положительный заряд; смещение $\mathrm{pH}$ суспензий наночастиц в кислую сторону; изменение потенциала мембраны митохондрий; возрастание активности ферментов и фитогормонов $[6,7]$.

Результаты анализов показали, что наночастицы кобальта (НЧ Со) и меди (НЧ Сu) с размером частиц до 20 нм и 35-65 нм соответственно, незначительно повлияли на гематологические показатели крови экспериментальных животных по сравнению с контрольной группой. До введения все показатели соответствовали 
нормальным значениям. После введения наблюдалось небольшое изменение миелограммы: так, например, повысилось содержание лейкоцитов на $38 \%$ в случае НЧ Си и на 39,3\% в случае НЧ Со по сравнению с контролем, оставаясь в пределах нормы, что можно объяснить стрессом при взятии крови. Процентное содержание компонентов практически не изменилось. Однако, такой показатель как СОЭ (скорость оседания эритроцитов) увеличился для НЧ Со в 3 раза, а для НЧ Сu - в 2 раза, в сравнении с контролем, что вероятно связано с увеличением содержания в плазме крупнодисперсных белков для НЧ меди, а для НЧ кобальта это говорит, скорее всего, о токсичности препарата.

При введении в рацион крыс НЧ ZnO (размер частиц 20-80 нм) количество эритроцитов, лейкоцитов и гемоглобина понизилось на $17,7 \%, 34,1 \%$ и $13,6 \%$ соответственно, по сравнению с контролем; а общий объем эритроцитов, распределение эритроцитов в крови и лимфоцитов повысилось на 13,9\%, 59,7\% и 18,5\% соответственно. Показатель СОЭ увеличился относительно контроля в 5,5 раз, что говорит о токсичности препарата. Введение Нч СuO (размер частиц 20-80 нм) способствовало повышению таких показателей как: распределение эритроцитов в крови (на 174,7\%), гемоглобина (на 4,8\%), сегментноядерных нейтрофилов (на18,75\%). Токсичность действия наночастиц не обнаружена.

Таким образом, все НЧ, кроме оксида цинка, который обладает более высокой растворимостью в биологических жидкостях не оказали токсичного действия на морфологические показатели крови.

Наночастицы меди и кобальта размером 35-60 нм изменяли биохимические показатели крови примерно в одинаковой степени. Наблюдалось увеличение креатинина соответственно под действием НЧ меди и кобальта на 18,5\% 18,05\%, глюкозы на 25,2\% и 26,0\%; понижение мочевины на 11,0\% и 11,8\%, общего билирубина на $23,0 \%$ и $22 \%$, АЛТ на $34,0 \%$ и $33 \%$, АСТ на $25,4 \%$ и $26 \%$ по сравнению с контролем.

Для определения влияния размеров наночастиц на биохимические показатели крови для одной группы опытных животных в рацион были введены НЧ Со размером 18-20 нм. Для этой группы произошло повышение в сравнении с контрольными значениями: креатинина на 38,46\%; общего билирубина - 133,3\%; пр. билирубина - 60,0\%; глюкозы - 17,5\%; общего белка 15,8\%; альбуминов - 39,3\%; альб./глоб.- 308,2\%; холестерола - 31,3\%. Коэффициент де Ритиса был повышен в 4,28 раза по отношению к контрольной группе и в 6,85 раза в сравнении с нормой. При этом снизились показатели АСТ на 25,2\%, АЛТ на 47,5\% и мочевины на 9,8\%. Все эти данные свидетельствуют о токсичном влиянии НЧ
Со (18-20нм) на внутренние органы (печень, почки). Возможно, это связано с размером применяемых частиц до 20 нм, которые могут легко проходить через мембраны клеток и влиять на внутриклеточный метаболизм. В работе [5] отмечено, что частицы малых размеров обладают высокой площадью удельной поверхности, крайне реакционноспособны и опасны для живых систем.

Для НЧ CuO: значения показателей понизились у мочевины на 19,7\%, АСТ на 17,3\%, в сравнении с контролем. Повысился общий билирубин на 16,7\%, щелочная фосфатаза на 38,7\%, общий белок на 7,42\%, глобулины на $12 \%$. При введении в рацион крыс НЧ ZnO снизились следующие показатели: мочевина на 18\%, АСТ на 21,6\%, АЛТ на $10,2 \%$, общий белок на $12,8 \%$ и фракция глобулина на 18,4\%. Повысилось содержание щелочной фосфатазы в 4 раза, что говорит о токсичном влиянии на костную ткань и клетки печени, почек. Коэффициент де Ритиса под действием наночастиц оксидов меди и цинка составил 1,77 и 1,82 соответственно, что ближе к норме $(1,3)$ по сравнению с контролем, где он равен 2,08.

Интересным направлением в современной науке стало исследование окислительной модификации белков (ОМБ) при патологических и адаптационных процессах. На сегодняшний день ОМБ признана одним из наиболее ранних и стабильных показателей поражения различных тканей организма при свободно-радикальной патологии [20, 21, 22]. Изучено воздействия наночастиц на окислительную модификацию белков на примере тимуса крыс в условиях применения наночастиц как модуляторов биохимических процессов. Исследование проводили на 54 крысах-самках линии Wistar массой 260-320 г. Животным (36 особей) экспериментальных групп в течение 14 дней перорально вводили суспензии наночастиц А меди (12 особей) и Б кобальта (12 особей) (размер частиц 35-60 нм): группе А1 и Б1 ( $n=6)$ в дозе $10^{-3}$ мг/кг (ранее установленная оптимальная концентрация для животных), а группе А2 и Б2 ( $=6)$ в дозе $10^{-1}$ мг/кг. Группе В (12 особей) вводили наночастицы оксида меди; группе C (12 особей) оксид цинка: В1 и С1 $10^{-3} \mathrm{Mr} /$ кг; В2 и С2 $10^{-1}$ мг/кг. Контрольной группе животных K ( $=6)$ в те же сроки осуществляли пероральное введение физиологического раствора.

Уровень образования карбонильных производных в тимусе крыс экспериментальных групп А, Б, В и С сопоставим, но в группах Б, В и С был выше значений окислительного спонтанного изменения белков контрольных животных соответственно на 2\% $11 \%$ и 18\% относительно контроля. У животных группы А2 наблюдалось незначительное изменение. Статистически достоверное, зависящее от доз, возрастание динитрофенилгидразонов при $\lambda=430$ и 530 нм для экспериментальных групп свидетельствует о более высоком образовании динитрофе- 
Таблица 1. Показатели интенсивность флуоресценциии, ед. на 1 г ткани

\begin{tabular}{|l|l|l|l|l|l|}
\hline Показатели & Контроль & В1 группа & В2 группа & С1 группа & С2 группа \\
\hline Битирозин & $4,26 \pm 1,51$ & $3,22 \pm 0,18$ & $3,04 \pm 0,21$ & $3,31 \pm 1,01$ & $3,69 \pm 0,48$ \\
\hline Триптофан & $11,8 \pm 2,14$ & $9,03 \pm 0,65$ & $8,52 \pm 0,43$ & $6,11 \pm 0,15^{*}$ & $5,22 \pm 0,32^{*}$ \\
\hline
\end{tabular}

* при $\mathrm{p}<0,05$

нилгидразонов основного характера. На длине волны 356 нм значимые различия имеются для Б, В группы животных, которым вводили суспензии наночастиц в дозе $10^{-1}$ мг/кг, они показывает преобладание образования альдегидных форм, которые характеризуют фрагментацию белков. Для С групп преобладание образования альдегидных форм характерно и при $10^{-3}$ мг/кг. Известно, что в поздних стадиях окислительного стресса происходит агрегация белковых молекул и преобладают вторичные маркеры - КДНФГ, которые незначительно содержаться в контрольной, А и Б1 группах.

В экспериментальных А, Б группах среди модифицированных белков преобладают АДНФГ над КДНФГ при введении наночастиц как в дозе $10^{-3}$ мг/кг, так и в дозе $10^{-1}$ мг/кг, что свидетельствует об обратимом характере окислительного стресса. В группах В2 и С2 в дозе $10^{-1}$ мг/ кг выявлено преобладание КДНФГ над АДНФГ, то есть процесс окислительного стресса переходит в позднюю стадию.

Для значений КДНФГ и АДНФГ основного и нейтрального характера прослеживается одна и та же закономерность: достоверное возрастание относительно контрольной группы их соотношения в результате увеличения вводимой дозы наночастиц оксида меди (В группа) и оксида цинка (С группа). Статистически значимые различия имеют место и между этими экспериментальными группами. Для В групп данное соотношение ниже на 8\%, чем для С группы. Следовательно, присутствие наночастиц оксида меди и цинка доззависимо приводит к аккумулированию окислительно-модифицированных белков, что может быть следствием истощения резервно-адаптационных возможностей клетки.

Тот факт, что в модифицированных группах белков (А и Б) выявлено преобладание АДНФГ над КДНФГ при введении НЧ меди и кобальта как в дозе $10^{-3} \mathrm{Mг} /$ кг, так и в дозе $10^{-1} \mathrm{Mr} /$ кг, свидетельствует, что при данных дозировках процесс окислительного стресса не переходит в развитую стадию и носит обратимый характер при этом идет процесс фрагментации белков с образованием низкомолекулярных фрагментов.

Источником низкомолекулярных фрагментов могут для групп В и С являться конечные продукты гидроксилирования пятичленной структуры индольного кольца триптофана, что подтверждается Этому соответствует достоверной зависимостью между вводимой дозой наночастиц и значительным гашением флуоресценции триптофановых остатков (таблица1).

Воздействие НЧ оксидов сопровождается окислительным повреждением белков в области остатков триптофана. Образование битирозина в экспериментальных условиях незначительно снижалось (таблица1). Известно, что ароматические аминокислоты редко входят в состав металлсвязывающей поверхности белков, поэтому они меньше подвергаются воздействию металл-катализируемого окисления. Кроме этого, незначительный уровень битирозина свидетельствует об отсутствии процессов агрегации и преобладании фрагментации белков.

Таким образом, в отличие от наночастиц металлов, НЧ оксиды стимулируют процессы окислительной деструкции белков в тимусе крыс. Это отражается на возможности обновления белков тканей.

\section{Выво $\triangle \mathrm{b}$}

1. Таким образом, если сравнивать НЧ кобальта и НЧ меди, размером 35-60нм по действию на морфологические и биохимические показатели крови, то они оказали положительное влияние на организм животного, стимулируя обменные процессы.

2. НЧ кобальта, обладая размером частиц до 20 нм оказали токсическое действие, они опасны для контакта с живыми системами.

3. Действие НЧ оксида меди не являются токсичным, но он тормозит обменные процессы как растений, так и животных. Оксид цинка оказывает токсичное влияние на костную ткань и клетки печени, почек. Возможно, это связано с более высокой растворимостью оксида цинка в биологических жидкостях.

4. Полученная зависимость воздействия наночастиц на окислительную модификацию белков демонстрирует снижение возможности обновления белков ткани тимуса в результате низкой активности клеточных протеазных систем в группах крыс получавших наночастицы оксидов меди

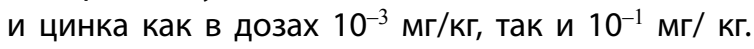


Патологическое влияние НЧ связано с образованием окисленных форм триптофана, преобладанием процессов фрагментации белковых молекул. Происходит изменение физико-химического состояния белков, нарушение их функций и истощению возможностей обновления белков тимуса.
5. Наночастицы металлов - меди и кобальта - в дозах $10^{-3} \mathrm{Mг/кг} \mathrm{и} 10^{-1}$ мг/кг показывают обратимый характер окислительного стресса.

Исследование выполнено при финансовой поддержке РФФИ в рамках научного проекта № 18-33-00510.

\section{ЛИТЕРАТУРА}

1. Polischuk S.D., Churilov G. I., Churilov D. G., Borychev S. N., Churilova V.V. Plants nutrition and growth stimulation with the help of nanotechnologies // International Journal of Engineering and Technology (UAE). 2018. Vol. 7. № 4.36. PP. 231-236.

2. Полищук С. Д., Голубева Н. И. Изменение лабораторной всхожести семян яровой пшеницы под воздействием обработки их ультрадисперсными материалами // Вестник Рязанского государственного агротехнологического университета им. П. А. Костычева. 2010. № 3 (7). С. $38-39$.

3. Чурилов Г. И. Влияние нанокристаллических металлов на состав и свойства полисахаридов растений / Г. И. Чурилов, Д. Г. Чурилов, М. Н. Горохова, С. Д. Полищук // Сельскохозяйственная техника: обслуживание и ремонт. 2017. № 8. С. 43-47.

4. Churilov, G.I., Polischuk S. D., Kuznetsov Denis., Borychev S. N., Byshov N. V. Churilov D. G. Agro ecological grounding for the application of metal nanopowders in agriculture//Int. J. Nanotechnol. 2018.Vol. 15, Nos. 4/5. PP. 258-279

5. Churilov, D. Size-dependent biological effects of copper nanopowders on mustard seedlings/ D Churilov, V Churilova, I Stepanova, S Polischuk, A Gusev, 0 Zakharova, I Arapov and G Churilov //Forestry 2019 IOP Conf. Series: Earth and Environmental Science. 2019012008, IOP Publishing 392 doi:10.1088/1755-1315/392/1/012008

6. Auffan, M. Towards a definition of inorganic nanoparticles from an environmental, health and safety perspective / M. Auffan, J. Rose, J.-Y. Bottero, G. V. Lowry, J.-P. Jolivet, M. R. Wiesner // Nature. Nanotechnology. 2009. V. 4, P. 634-641

7. Boldyreva, A. A. Biochemistry of membranes / A. A. Boldyreva // Edocytosis and exocytosis. 1987. M., V. 2, P. 95

8. Bulychev, A. G. Segregation function of the cell and its molecular mechanisms / A. G. Bulychev // Cytology 1986. V. 28, I. 4, P. 387-402

9. Чурилов Д.Г., Чурилова В. В., Обидина И. В., Чурилов Г. И., Степанова И. А., Биологическая активность наночастиц кобальта и оксида цинка и их биоаккумуляция на примере вики.// Вестник Рязанского государственного агротехнологического университета им. П. А. Костычева. 2019. № 1 (41). С. 62-67.

10. Тихомиров, С. А. Низкотемпературное водородное восстановление кобальтовых порошков / С. А. Тихомиров, И. В. Трегубова, М. И. Алымов, О. Д. Тарасов, Н. Ф. Коровкина // Физика и химия обработки материалов. — 2010.— № 6.—C. 73-76.

11. Скулачев, В. П. Законы биоэнергетики/ Скулачев В. П. // Соросовский Образовательный Журнал.-1997.-№ 1.-С. 9-14.

12. Романовский, Ю. М. Молекулярные преобразователи живой клетки. Протонная АТФ-синтаза — вращающийся мотор / Ю. М. Романовский, А. Н. Тихонов // Успехи физических наук. - 2010.— - Том 180.— № 9.— С 932-956.

13. Векилова, Г.В.Дифракционные и микроскопические методы и приборы для анализа наночастици наноматериалов/ Г.В.Векилова, А. Н. Иванов, Ю. Д. Ягодкин: Москва, МИСиС.-2009.- 145 с.

14. А.А. Носенко, С. И. Половнева, Методы и устройства для измерения удельной поверхности наноматериалов/ А. А. Носенко, С. И. Половнева// — Известия вузов. Прикладная химия и биотехнология. - 2017.- Том 7.— № 2.—C 113-121.

15. Дубинина, Е. Е. Продукты метаболизма кислорода в функциональной активности клеток / Е. Е. Дубинина // — СПб.: Медицинская пресса, 2006. — 400 с.

16. Дубинина, Е. Е. Окислительная модификация белков сыворотки крови человека. Метод её определения / Е. Е. Дубинина, С. О. Бурмистров, Д. А. Ходов, И. Г. Поротов // Вопросы мед. химии. - Т. 41, № 1. - 1995.—C. 24-26.

17. Толочко, 3.С., Спиридонов В.К. Окислительная модификация белков в крови крыс при повреждении капсаицинчувствительных нервов и изменении уровня оксида азота/ З. С. Толочко, В. К. Спиридонов // Российский физиологический журнал им. И. М. Сеченова. — 2010.— Т. 96, № 1. — С. $77-84$.

18. Amado R. Dytirosine: in vitro production and characterization/ R. Amado, R. Aeschbach, H. Neukom // Methods Enzymol.— 1984.—Vol. 107.—P. 377-388.

19. Teale F.W.J. Ultraviolet fl uorescence of proteins in neutral solution/ F.W.J. Teale // Biochem. J. 1960. Vol. 76, no. 2 pp. 381-388.

20. Зенков, Н. К. Окислительный стресс: биохимический и патофизиологический аспекты/ Н. К. Зенков, В. З. Ланкин, Е. Б. Меньщикова // М.: МАИК, 2001. 343 с.

21. Муравлева Л.Е. Окислительная модификация белков: проблемы и перспективы исследования / Л. Е. Муравлева // Фундаментальные исследования.2010.—№ 1.—C. 74-78.

22. Dalle-Donne I. Protein carbonyl groups as biomarkers of oxidative stress / I. Dalle-Donne // Clinica Chimica Acta. — 2003.— № 329.—P. 23-38.

23. Полищук, С. Д. Ветеринарно-санитарная оценка продуктов убоя цыплят-бройлеров при использовании наночастиц селена / С. Д. Полищук, Л. Е. Амплеева, А. А. Коньков // Зоотехния.— 2015.—№ 8.-С. 31-32.

24. Амплеева, Л. Е. Физиологическое состояние кроликов при введении в рацион вики, выращенной с использованием ультрадисперсных порошков железа и кобальта: автореф. дис. на соискание уч.степени канд. биол. наук [Текст]/Л.Е. Амплеева; РГСХА.— Рязань, 2006.

○ Чурилов Геннадий Иванович ( genchurilov@yandex.ru ), Обидина Инна Вячеславовна ( inna.obidina@mail.ru ),

Чурилов Дмитрий Геннадьевич ( churilov.dmitry@yandex.ru ), Чурилова Вероника Вячеславовна, Полищук Светлана Дмитриевна ( svpolishuk@mail.ru ). Журнал «Современная наука: актуальные проблемы теории и практики» 